\title{
ABIOTIC AND BIOTIC FACTORS AFFECTING THE OCCURRENCE OF THRIPS ON LOTUS FLOWERS
}

\author{
BUMROONGSOOK, S. \\ Department of Plant Production Technology, Faculty of Agricultural Technology, King \\ Mongkut's Institute of Technology Ladkrabang, Bangkok 10520, Thailand \\ (e-mail:suvarin.bu@kmitl.ac.th) \\ (Received $13^{\text {th }}$ Feb 2018; accepted $9^{\text {th }}$ May 2018)
}

\begin{abstract}
Frankliniella schultzei Trybom and Scirtothrips dorsalis Hood are two important insect pests of lotus flowers (Nulumbo nucifera Gearn). Both are active throughout the year and are difficult to control during pre- and post- harvest management. This study is focused on factors that influence the relationship among the thrips, their host plants and abiotic factors. Therefore, the distribution of these thrips species within lotus flowers of different flower ages was assessed using randomly sampling from commercially growing areas in Bangkok, Thailand and investigated thrips abundance on these flowers every week from April to September, 2016. The results revealed that there was a higher thrips population on older lotus flowers. S. dorsalis was much more abundant in summer than in the rainy season. It was found mainly on the pedicel and the outer corolla of the flowers. In the summer and rainy season, $F$. schultzei occurred most often and were found on the distal parts of lotus petals and pollen areas. Hindu lotus and East Indian lotus could support more of $F$. schultzei and S. dorsalis than Album Plenum and Roseum Plenum. The correlation among abiotic factors (temperature, amount of rainfall and relative humidity) and population fluctuations of S. dorsalis and F. schultzei was assessed. The studies showed a positive correlation of temperature $(\mathrm{r}=$ $0.7918)$ and a negative correction of relative humidity $(\mathrm{r}=-0.7588)$ to population of $S$. dorsalis but no relation with amount of rainfall $(\mathrm{r}=0.0260)$. Whereas, there were non-significant correlations among $F$. schultzei and temperature $(\mathrm{r}=0.43650$, relative humidity $(\mathrm{r}=-0.2113)$ and rainfall $(\mathrm{r}=-0.4164)$. Interactions between different temperatures, relative humidity and rainfall effects on the abundance of the thrips were seen here. Both fundamental and applied perspectives will provide better understanding the thrips population abundance, and help to develop management plans for thrips control.
\end{abstract}

Keywords: F. schultzei, population fluctuation, $S$. dorsalis, relative humidity, rainfall

\section{Introduction}

Currently, insect pests are an important factor in lotus farming that affect the quantity and quality of the agricultural product. Farmers use chemicals as the primary measure to prevent damage caused by insects. Thrips are major enemies of both vegetable crops and ornamental plants. They use their stylets to obtain water and liquid nutrients from various plant cells including shoots, flowers and leaves, which results in a pale color or dry edges of affected plant tissue. The insects are highly polyphagous. Both Scirtothrips dorsalis Hood (chilli thrips) and Frankliniella schultzei Trybom (common blossom thrips) are two important insect pests of lotus flowers (Nulumbo nucifera Gearn) grown for export (Mungnimitr and Bumroongsook, 2007). The chilli thrips is a serious insect pest of lotus, agricultural crops and various floral plants. It is most often found feeding on young shoots and leaves and causes scars on fruit surface (Seal and Klassen, 2008).

The common blossom thrips are abundant on sacred lotus in Thailand (Mound and Palmer, 1981). It is an anthophilous insect and often feed on the floral parts of its host plant (Kakkar et al., 2012b), and is capable of destroying parts of the lotus flower. Both larvae and adults usually stay at the base of the petals and feed on plant cells (Mungnimitr and Bumroongsook, 2007), but can feed on other plant parts such as petals and leaves (Milne et al., 1996). It is a highly polyphagous insect, infesting a wide range of vegetable 
crops and ornamental plants (Moritz et al., 2013). The thrips aggregate and colonize on plant petals (Milne et al., 2002) and can also pollinate various host plants (Kirk, 1997), although they can disfigure ornamental flowers in the process. Heavy infestation can discolor of flowers and distort the growth of young shoots (Amin and Palmer, 1985). Both forms of $F$. schultzei (dark and pale forms) can also be insect vectors for virus transmission (Nagata and De Avila, 2000; Cho et al., 1988).

Abiotic and biotic factors work in combination to shape species distributions and abundance (Lewis et al., 2017). Temperature is one of the important abiotic factors that affects abundance, distribution and population dynamics of insects (Kang et al., 2009; Yadav and Chang, 2014). Thrips population had a positive correlation with temperature and showed a negative correlation with relative humidity (Shuaib et al., 2008). Climatic factors are important factors that significantly influence thrips density as well (Kirk, 1997; Waiganjo et al., 2008). High temperatures with no rainfall increased thrips populations, while high relative humidity and rainfall had a negative relationship (Hamdy and Salem, 1994).

Biotic factors associated with host plants can affect species distributions and abundance. Plant aging increased mortality and influenced larval development of thrips (Campos et al., 2003). A nutrient supplement (nectar/pollen) is essential for insect survival in the absence of prey, or a modified microhabitat which can protect it against severe abiotic conditions (Xiao et al., 2011). Asian lotus flower is a concave shape and without nectar, having a cavity surrounded by petals and stamens and releasing scent. The flower has a thermoregulation process that can control temperature during anthesis and an optimum temperature between 30 and $36{ }^{\circ} \mathrm{C}$ when the environmental temperature is between 10 and $45^{\circ} \mathrm{C}$ (Seymour et al., 1998; Seymour and Schultze-Motel, 1996; Xiao et al., 2011). Thrips are a lotus flower pollinator. The level of plant damage is dependent on S. dorsalis density (Mannion et al., 2014).

The objectives of this research are to determine seasonal population fluctuation and within lotus flower distribution of $F$. schultzei and $S$. dorsalis. The correlation of abiotic factors: temperature, relative humidity and amount of rainfall and population abundance of thrips on lotus flowers were evaluated. Understanding the influence of these abiotic and biotic factors on thrips abundance can help to further develop more efficient management programs for thrips control.

\section{Materials and methods}

\section{Location of the sample sites}

The experimental sites were located in Ladkrabang district of Bangkok province. Eleven sites of sample collection were chosen based on lotus varieties and non pesticidetreated areas (Fig. 1). GPS coordinates for location and the distance from sample sites to the data logger including the lotus plant variety were illustrated in Table 1. S1 and S2 are the experimental sites for collection of Hindu lotus (a single white flower); S3 and S4 for Album Plenum (a double white flower); S5-S6 for East Indian lotus (a single pink flower); and S7-S11 for Roseum Plenum (a double pink flower, Table 1).

\section{Population density of S. dorsalis and F. schultzei on different stages of lotus flowers}

Differently aged lotus flowers ( $N$. nucifera var. Roseum Plenum), i.e., small bud, standard bud and full bloom (5, 9 and 13 days above water level, respectively; $n=30)$, 
were collected weekly from non-chemical lotus farms in Ladkrabang area, Bangkok, Thailand. Direct thrips count was performed using a stereomicroscope and total number of thrips found on each type of flower was recorded.

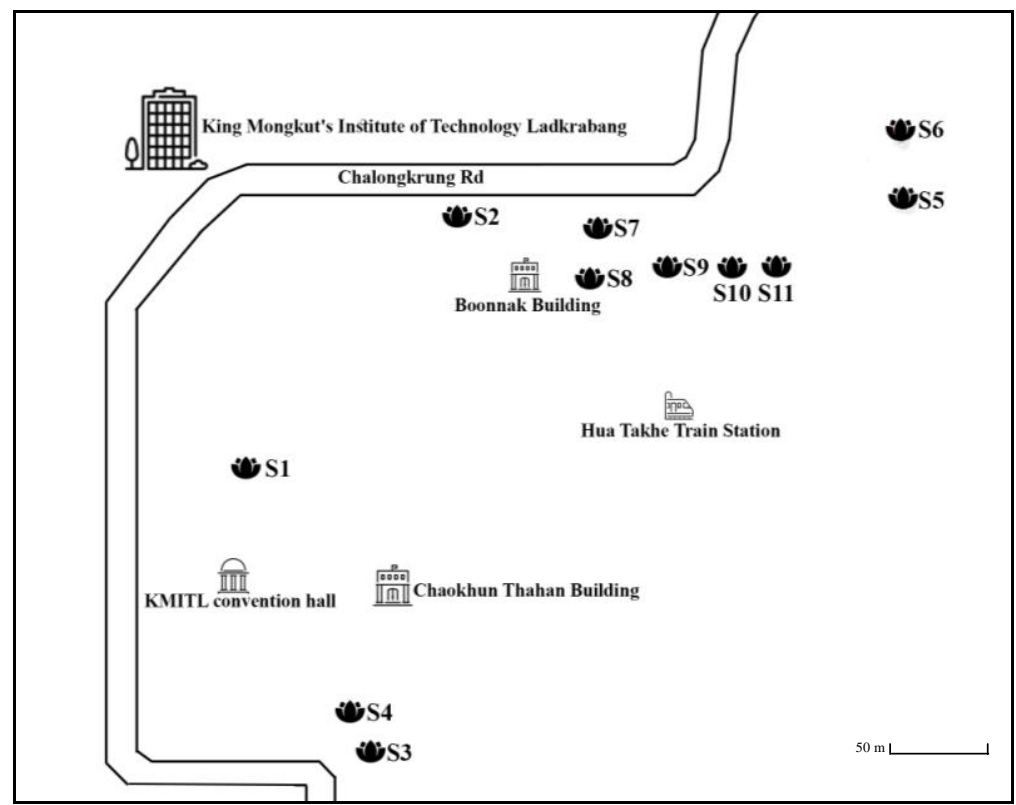

Figure 1. Location of the sample sites in Ladkrabang district

Table 1. Description of eleven sample sites located in Ladkrabang district, Bangkok, Thailand

\begin{tabular}{|c|c|c|c|}
\hline Sample sites & Location & $\begin{array}{c}\text { Distance to the data } \\
\text { logger }(\mathrm{km})\end{array}$ & Lotus varieties \\
\hline $\mathrm{S} 1$ & 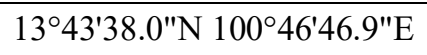 & 0.200 & Hindu lotus \\
\hline $\mathrm{S} 2$ & $13^{\circ} 43^{\prime} 48.6^{\prime \prime} \mathrm{N} 100^{\circ} 46^{\prime} 53.4^{\prime \prime} \mathrm{E}$ & 0.126 & Hindu lotus \\
\hline $\mathrm{S} 3$ & $13^{\circ} 43^{\prime} 30.1^{\prime \prime} \mathrm{N} 100^{\circ} 46^{\prime} 49.7^{\prime \prime E}$ & 0.286 & Album Plenum \\
\hline $\mathrm{S} 4$ & $13^{\circ} 43^{\prime} 30.8^{\prime \prime} \mathrm{N} 100^{\circ} 46^{\prime} 49.3^{\prime \prime} \mathrm{E}$ & 0.578 & Album Plenum \\
\hline S5 & $13^{\circ} 43^{\prime} 49.2^{\prime \prime} \mathrm{N} 100^{\circ} 47^{\prime} 09.3^{\prime \prime} \mathrm{E}$ & 0.318 & East Indian lotus \\
\hline S6 & $13^{\circ} 43^{\prime} 51.7^{\prime \prime} \mathrm{N} 100^{\circ} 47^{\prime} 09.2^{\prime \prime} \mathrm{E}$ & 0.340 & East Indian lotus \\
\hline S7 & $13^{\circ} 43^{\prime} 48.3^{\prime \prime} \mathrm{N} 100^{\circ} 46^{\prime} 58.2^{\prime \prime} \mathrm{E}$ & 0.020 & Roseum Plenum \\
\hline S8 & $13^{\circ} 43^{\prime} 46.9^{\prime \prime} \mathrm{N} 100^{\circ} 46^{\prime} 57.7^{\prime \prime} \mathrm{E}$ & 0.047 & Roseum Plenum \\
\hline S9 & $13^{\circ} 43^{\prime} 47.6^{\prime \prime} \mathrm{N} 100^{\circ} 46^{\prime} 59.5^{\prime \prime} \mathrm{E}$ & 0.043 & Roseum Plenum \\
\hline $\mathrm{S} 10$ & $13^{\circ} 43^{\prime} 47.6^{\prime \prime} \mathrm{N} 100^{\circ} 47^{\prime} 00.7^{\prime \prime} \mathrm{E}$ & 0.074 & Roseum Plenum \\
\hline $\mathrm{S} 11$ & $13^{\circ} 43^{\prime} 47.6^{\prime \prime} \mathrm{N} 100^{\circ} 47^{\prime} 01.5^{\prime \prime} \mathrm{E}$ & 0.101 & Roseum Plenum \\
\hline
\end{tabular}

Comparison of the abundance of S. dorsalis and F. schultzei on different parts of lotus flower

Standard buds of Roseum Plenum lotus flowers $(n=30)$ were collected and thrips count on its pedicel, petals and pollen areas of lotus cut flower were performed. Thrips density of $S$. dorsalis and $F$. schultzei from these flower parts was identified and recorded. 


\section{Number of thrips on the different corolla of lotus flowers}

Roseum Plenum lotus flowers are composed of six corolla: the first corolla are the outermost petas, and the innermost petals are the sixth corolla. Standard lotus flowers var. Roseum Plenum $(n=30)$ were collected weekly. Thrips count on each corolla were investigated.

\section{Thrips abundance on different varieties of lotus flowers}

A total of 30 lotus flowers were randomly selected from each of four varieties of $N$. nucifera: Hindu lotus (a single white flower), Album Plenum (a double white flower), East Indian lotus (a single pink flower) and Roseum Plenum (a double pink flower). Number of thrips found on lotus was investigated and recorded.

\section{Correlation among thrips population abundance and temperature, relative humidity and rainfall}

A total of 30 Roseum Plenum lotus flowers were randomly selected. Thrips counts of $S$. dorsalis and F. schultzei on each flower and its pedicel was performed. For the temperature and relative humidity dataset, a data logger (DT172-CEM G M Electronics) was used to record air temperature and relative humidity every hour The weather data (daily average observation for air temperature and relative humidity) was computed. The data logger was placed on the wall of the storage house ( $5 \mathrm{~m}$ from S7) at $1.5 \mathrm{~m}$ above the ground with protective roof. The amount of rainfall at Ladkrabang area obtained from the Thai Meteorological Department.

\section{Data collection and statistical analysis}

The experimental period was spread out across two seasons: summer (April-May, 2016) and rainy season (June-September, 2016). Samples were collected once a month for six months and processed independently for each experiment. To reduce light intensity variation effect on thrips population, all samples were collected between 7 and 9 am. Thrips were collected from plant parts, then transferred in $70 \%$ ethanol for later analysis. They were identified to species using a stereomicroscope. The SPSS statistical software was used to perform data analysis. Population density of thrips were analyzed separately for each experiment using the paired sample t-test to determine the mean difference between density of $S$. dorsalis and $F$. schultzei. ANOVA was applied to assess the mean difference of thrips occurrence among lotus varieties. Linear regression analysis was used to assess correlation among thrips occurrence and abiotic factors.

\section{Results}

Population density of $S$. dorsalis and $F$. schultzei on different stages of Roseum Plenum lotus flowers

Thrips counts on the same type of flower buds were compared and the results showed that the older the flower buds were, the more thrips were found. In the small flower buds, no difference was found in the density of $F$. schultzei detected than $S$. dorsalis $(\mathrm{t}$-value $=1.29$ and $\mathrm{p}=0.1125) . F$. schultze $i$ were found more than $S$. dorsalis in the standard-sized buds $(\mathrm{t}=2.19$ and $\mathrm{p}=0.0264)$ and the full bloom lotus flowers 
$(\mathrm{t}=3.11$ and $\mathrm{p}=0.0054$; Table 2). F. schultzei was found the most on full bloom lotus flowers.

Comparison of the abundance of $S$. dorsalis and F. schultzei on diffirent parts of Roseum Plenum lotus flowers

S. dorsalis was found on flower pedicel and petals and none were detected in the middle area of flowers (containing pollen and stamen). Comparing $S$. dorsalis and $F$. schultzei occurrence on flower pedicels, the result showed no significant difference $(\mathrm{t}=1.46$ and $\mathrm{p}=0.0869)$. F. schultzei were detected more than $S$. dorsalis on lotus flower petals $(\mathrm{t}=2.82$ and $\mathrm{p}=0.0091)$, as well as stamen and pollen areas $(\mathrm{t}=2.56$ and $\mathrm{p}=0.0141 ;$ Table 3).

Table 2. Population density of $S$. dorsalis $(S)$ and $F$. schultzei $(F)$ on different stages of Roseum Plenum lotus flower

\begin{tabular}{c|c|c|c|c|c|c}
\hline \multirow{2}{*}{$\begin{array}{c}\text { Months } \\
(\mathbf{2 0 1 6})\end{array}$} & \multicolumn{6}{|c}{ Thrips density on different stages of flower } \\
\cline { 2 - 7 } & \multicolumn{2}{|c|}{ Small bud } & \multicolumn{2}{c}{ Standard bud } & \multicolumn{2}{c}{ Full bloom } \\
\cline { 2 - 7 } & S & F & S & F & S & F \\
\hline April & 0.16 & 3.42 & 1.20 & 3.04 & 7.09 & 14.31 \\
May & 0.68 & 2.03 & 2.55 & 16.03 & 2.75 & 48.70 \\
June & 0.44 & 0.49 & 0.96 & 7.73 & 0.68 & 20.69 \\
July & 1.18 & 0.90 & 0.63 & 1.78 & 0.35 & 16.58 \\
August & 1.08 & 0.91 & 0.08 & 9.01 & 0.01 & 30.51 \\
September & 0.00 & 0.00 & 0.00 & 0.00 & 0.73 & 2.867 \\
\hline
\end{tabular}

Table 3. Number of $S$. dorsalis $(S)$ and $F$. schultzei $(F)$ found on different parts of Roseum Plenum lotus flowers

\begin{tabular}{|c|c|c|c|c|c|c|}
\hline \multirow{3}{*}{$\begin{array}{c}\text { Months } \\
(\mathbf{2 0 1 6})\end{array}$} & \multicolumn{6}{|c|}{ Thrips density } \\
\hline & \multicolumn{2}{|c|}{ Flower pedicel } & \multicolumn{2}{|c|}{ Petal } & \multicolumn{2}{|c|}{ Pollen and stamen } \\
\hline & $\mathbf{S}$ & $\mathbf{F}$ & $\mathbf{S}$ & $\mathbf{F}$ & $\mathbf{S}$ & $\mathbf{F}$ \\
\hline April & 1.87 & 0.00 & 1.29 & 0.86 & 0.00 & 4.99 \\
\hline May & 0.38 & 0.42 & 0.52 & 7.24 & 0.00 & 17.43 \\
\hline June & 0.37 & 0.05 & 0.87 & 0.78 & 0.00 & 3.02 \\
\hline July & 0.09 & 0.00 & 0.96 & 2.94 & 0.00 & 3.48 \\
\hline August & 0.30 & 0.00 & 0.08 & 7.01 & 0.00 & 6.46 \\
\hline September & 0.00 & 0.00 & 0.22 & 6.69 & 0.00 & 1.21 \\
\hline
\end{tabular}

\section{Number of thrips on the different corolla of Roseum Plenum lotus flowers}

$S$. dorsalis were found from the first to the third corolla of Roseum Plenum flowers (Table 4). F. schultzei could be located from the outermost to the innermost corollas (Table 5). Density of $F$. schultzei appeared higher than $S$. dorsalis on different corolla.

\section{Thrips abundance on different varieties of lotus flowers}

S. dorsalis occurrence peaked in April and decreased gradually from May to September. They preferred Hindu lotus and East Indian lotus followed by Album Plenum and Roseum Plenum (Table 6). F. schultzei was found most in East Indian lotus during April and May, 2016 and its population was highest in Hindu lotus from June to 
September, 2016 (Table 7). F. schultzei was detected more in Roseum Plenum in May and June than Album Plenum.

Table 4. Population density of $S$. dorsalis on different corolla of Roseum Plenum lotus flowers

\begin{tabular}{c|c|c|c|c|c|c}
\hline \multirow{2}{*}{$\begin{array}{c}\text { Months } \\
\text { (2016) }\end{array}$} & \multicolumn{7}{|c}{ Population density of $\boldsymbol{S}$. dorsalis on the corolla no. } \\
\cline { 2 - 6 } & $\mathbf{1}$ & $\mathbf{2}$ & $\mathbf{3}$ & $\mathbf{4}$ & $\mathbf{5}$ & $\mathbf{6}$ \\
\hline April & 5.98 & 1.93 & 1.35 & 0.00 & 0.00 & 0.00 \\
May & 1.40 & 0.62 & 0.73 & 0.00 & 0.20 & 0.00 \\
June & 0.22 & 0.11 & 0.04 & 0.00 & 0.00 & 0.00 \\
July & 0.62 & 0.15 & 0.33 & 0.00 & 0.00 & 0.00 \\
August & 0.04 & 0.00 & 0.00 & 0.00 & 0.00 & 0.00 \\
September & 0.11 & 0.02 & 0.02 & 0.00 & 0.00 & 0.00 \\
\hline
\end{tabular}

Table 5. Population density of F. schultzei on different corollas of Roseum Plenum lotus flowers

\begin{tabular}{c|c|c|c|c|c|c}
\hline \multirow{2}{*}{$\begin{array}{c}\text { Months } \\
(\mathbf{2 0 1 6})\end{array}$} & $\mathbf{6}$ Population density of $\boldsymbol{F}$. schultzei on the corolla no. \\
\cline { 2 - 7 } & $\mathbf{1}$ & $\mathbf{2}$ & $\mathbf{3}$ & $\mathbf{4}$ & $\mathbf{5}$ & $\mathbf{6}$ \\
\hline April & 0.02 & .0 .31 & 0.00 & 0.00 & 0.00 & 0.00 \\
May & 0.31 & 2.24 & 0.47 & 1.80 & 0.82 & 0.91 \\
June & 0.18 & 9.40 & 0.04 & 5.44 & 0.71 & 0.91 \\
July & 0.15 & 22.58 & 0.31 & 8.56 & 2.27 & 2.24 \\
August & 0.20 & 19.27 & 0.13 & 7.56 & 1.91 & 0.78 \\
September & 0.00 & 8.04 & 0.00 & 3.31 & 1.49 & 0.02 \\
\hline
\end{tabular}

Table 6. Population density of S. dorsalis on different varieties of lotus flower

\begin{tabular}{c|c|c|c|c}
\hline \multirow{2}{*}{$\begin{array}{c}\text { Months } \\
(2016)\end{array}$} & Hindu lotus & Album Plenum & East Indian lotus & Roseum Plenum \\
\cline { 2 - 5 } & $21.80 \mathrm{~b}$ & $16.04 \mathrm{~b}$ & $36.04 \mathrm{a}$ & $3.60 \mathrm{c}$ \\
April & $21.75 \mathrm{a}$ & $3.91 \mathrm{bc}$ & $9.04 \mathrm{~b}$ & $2.07 \mathrm{c}$ \\
May & $6.51 \mathrm{a}$ & $1.02 \mathrm{~b}$ & $1.42 \mathrm{~b}$ & $3.27 \mathrm{ab}$ \\
June & $6.62 \mathrm{a}$ & $1.02 \mathrm{~b}$ & $1.42 \mathrm{~b}$ & $3.27 \mathrm{ab}$ \\
July & $0.47 \mathrm{a}$ & $0.09 \mathrm{a}$ & $2.71 \mathrm{a}$ & $0.44 \mathrm{a}$ \\
August & $0.00 \mathrm{~b}$ & $0.18 \mathrm{~b}$ & $1.69 \mathrm{a}$ & $0.35 \mathrm{~b}$ \\
September &
\end{tabular}

${ }^{1}$ Within rows, means followed by the same letters are not significantly different $(\mathrm{P}=0.05, \mathrm{DMRT})$

Table 7. Population density of $F$. schultzei on different varieties of lotus flower

\begin{tabular}{c|c|c|c|c}
\hline \multirow{2}{*}{$\begin{array}{c}\text { Months } \\
\text { (2016) }\end{array}$} & \multicolumn{3}{|c}{ Number of $\boldsymbol{F}$. schultzei $^{\mathbf{1}}$} \\
\cline { 2 - 5 } Hindu lotus & Album Plenum & East Indian lotus & Roseum Plenum \\
\hline April & $14.05 \mathrm{~b}$ & $1.07 \mathrm{~b}$ & $57.27 \mathrm{a}$ & $2.58 \mathrm{~b}$ \\
May & $12.09 \mathrm{c}$ & $3.33 \mathrm{c}$ & $73.62 \mathrm{a}$ & $28.95 \mathrm{~b}$ \\
June & $34.49 \mathrm{a}$ & $1.36 \mathrm{c}$ & $11.53 \mathrm{bc}$ & $14.60 \mathrm{~b}$ \\
July & $143.67 \mathrm{a}$ & $20.07 \mathrm{c}$ & $54.00 \mathrm{~b}$ & $11.78 \mathrm{c}$ \\
August & $185.15 \mathrm{a}$ & $10.24 \mathrm{c}$ & $141.95 \mathrm{~b}$ & $35.07 \mathrm{c}$ \\
September & $20.37 \mathrm{a}$ & $0.00 \mathrm{c}$ & $7.33 \mathrm{~b}$ & $0.27 \mathrm{c}$ \\
\hline
\end{tabular}

\footnotetext{
${ }^{1}$ Within rows, means followed by the same letters are not significantly different $(P=0.05, \mathrm{DMRT})$
} 


\section{Correlation among thrips population abundance and temperature, relative humidity and rainfall}

The climatic conditions from April to September, 2016 in the study area ranged from $27.20-32.57{ }^{\circ} \mathrm{C}$, RH $72-83 \%$ and rainfall $0-19 \mathrm{~mm}$ (Table 8). S. dorsalis density on lotus flower was highest in April and deceased gradually to 10.85, 11.68 and 7.85 in May, June and July, respectively. In August and September, there were 1.17 and 1.45 thrips/flower, respectively (Fig. 2). F. schultzei density was highest in August and lowest in June. The correlation between the amount of thrips on lotus flower over the five months of sampling and the abiotic factors temperature, relative humidity and rainfall was statistically analyzed. The results showed that temperature and relative humidity were significantly correlated with the change in $S$. dorsalis $(\mathrm{r}=0.7918$ and 0.7588 , respectively). $F$. schultzei density on lotus flowers was not significantly correlated to temperature, relative humidity and rainfall (Table 9).

Table 8. Abiotic condition of temperature, relative humidity and rainfall during the sampling periods

\begin{tabular}{c|c|c|c}
\hline Months (2016) & Temp $\left.\boldsymbol{~}^{\mathbf{0}} \mathbf{C}\right)$ & RH (\%) & Rainfall $(\mathbf{m m})$ \\
\hline April & 32.57 & 72 & 0.00 \\
May & 28.20 & 80 & 8.95 \\
June & 30.36 & 75 & 19.00 \\
July & 28.60 & 79 & 1.50 \\
August & 29.50 & 75 & 0.68 \\
September & 27.20 & 83 & 0.00 \\
\hline
\end{tabular}

\section{Discussion}

Both abiotic and biotic factors affect insect population abundance (Lewis et al., 2017). S. dorsalis is a polyphagous insect pest with a global distribution (Dickey et al., 2015). It feeds on meristem and young plant parts. $S$. dorsalis prefers the outer corolla of lotus flower and its pedicel. In addition, it feeds on lotus leaves (Mungnimitr and Bumroongsook, 2007). F. schultzei primarily attacked lotus flowers and caused discoloration. The female deposits egg on flower tissue and it takes about 13 days to complete life cycle (Kakkar et al., 2012a). F. schultzei was observed on full bloom lotus flowers. Aggregation density of insects on host plant corollas induce mating success (Kang et al., 2009). High density of $F$. schultzei on lotus flowers was similar to the finding of Kakkar et al. (2012b), who reported that adult are the most numerous in tomato flower.

As noted above, Hindu lotus and East Indian lotus are categorized as a single flower and Album Plenum and Roseum Plenum are a double flower (Mandal and Bar, 2013). The structure of single lotus flowers could allow $F$. schultzei to build up populations more easily than double lotus flowers. Further studies should be investigated if various colors of lotus flowers attract thrips to different degrees.

The lower the relative humidity value and the higher the temperature, the higher the number of $S$. dorsalis observed. Previous research reported similar results on relationship among temperature, relative humidity and thrips population (Hamdy and Salem, 1994). S. dorsalis was found on leaves and the outer parts of lotus flowers, therefore it is more exposed to the environmental condition than F. schultzei. On the contrary, F. schultzei density on lotus flowers might not depend on the abiotic factors 
like temperature, relative humidity and rainfall due to its cryptic habitat. The microhabitat within flowers could play important roles on observed population of thrips (Salguero_Navas et al., 1991).

\section{Thrips population fluctuation}

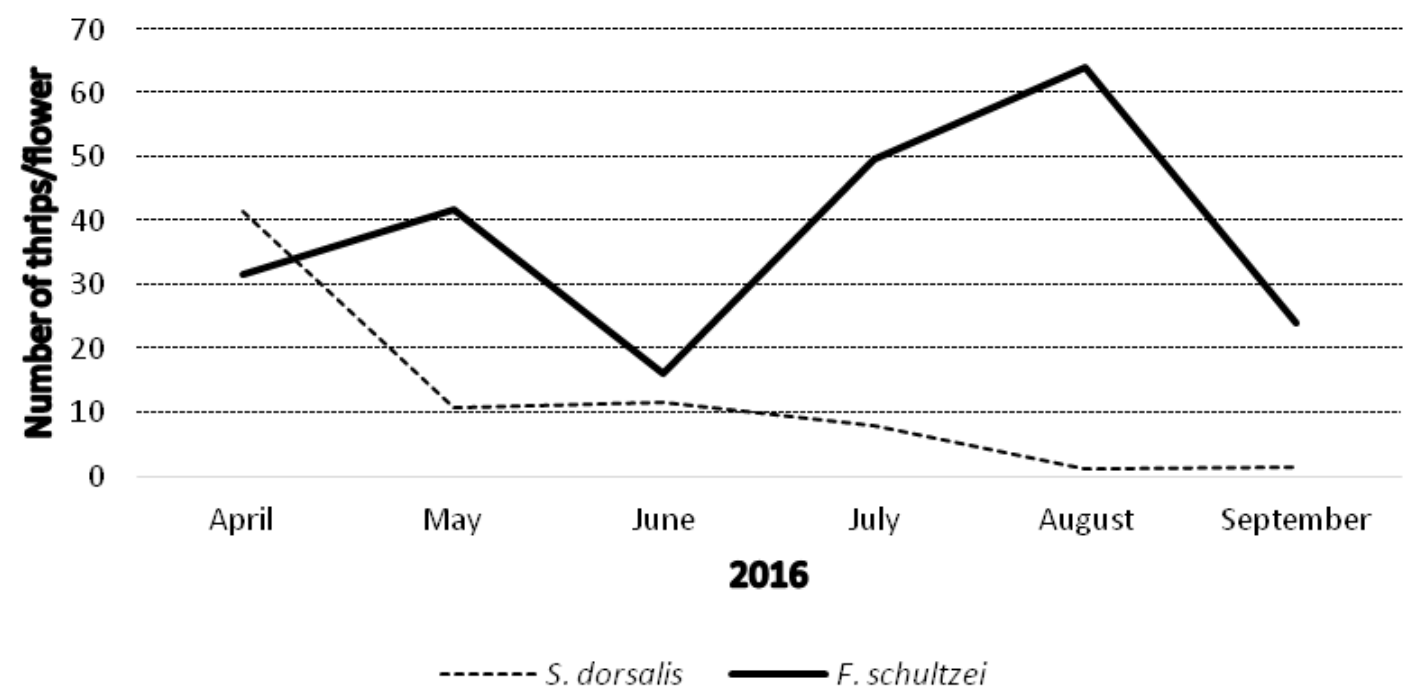

Figure 2. Population density of thrips on lotus flowers

Table 9. Correlation of population density of $S$. dorsalis and F. schultzei and temperature, relative humidity and rainfall

\begin{tabular}{c|c|c|c}
\hline \multirow{2}{*}{ Thrips species } & \multicolumn{3}{|c}{ Correlation coefficient } \\
\cline { 2 - 4 } & Temperature & Relative humidity & Rainfall \\
\hline S. dorsalis & $0.7918^{*}$ & $-0.7588^{*}$ & -0.0260 \\
& $(0.8899)$ & $(0.8711)$ & $(0.1613)$ \\
F. schultzei & 0.4365 & 0.2113 & 0.4164 \\
& $(0.6607)$ & $(0.4597)$ & $(0.6453)$ \\
\hline
\end{tabular}

$(\mathrm{R})=$ values in parentheses are $\mathrm{R}$ adjusted

*Statistically difference at $\mathrm{p}=0.05$

\section{Conclusions}

S. dorsalis attacked flower pedicels and the outer part of lotus petals and population peak during high temperature and dry weather. Abiotic factors such as the temperature and relative humidity played a remarkable role on $S$. dorsalis abundance. Regarding $F$. schultzei, this is the first report that they attack four varieties of lotus flowers. The $F$. schultzei mainly inhabit and feed on the petals and the pollen areas of lotus flower. Biotic factors (age of host plant and food selection) shaped the distribution and abundance of $F$. schulzei. In addition, lotus flower structures as protective shelter and microclimate within the flowers are factors that influenced the population abundance of F. schulzei. Size and cryptic behavior of these thrips make them difficult to control. Therefore, phytosanitary treatment of these thrips for lotus cut flowers export is probably the most challenging task. 
Acknowledgements. Thanks go to Assoc. Prof. Saen Tigwattananont for thrips identification. My thanks also extend to Ms Sayomporn Pleansri, King Saengkoso and undergraduate students who participated in all aspects of data collection.

\section{REFERENCES}

[1] Amin, P. W., Palmer, J. M. (1985): Identification of groundnut Thysanoptera. - Tropical Pest Management 31(4): 286-291.

[2] Campos, W. G., Schoereder, J. H., Picancol, M. C. (2003): Performance of an oligophagous insect in relation to the age of the host plant. - Neotropical Entomology 32(4): 671-676.

[3] Cho, J. J., Mau, R. F. L., Hamasaki, R. T., Gonsalves, D. (1988): Detection of tomato spotted wilt virus in individual thrips by enzyme-linked immunosorbent assay. Phytophathology 78: 1348-1852.

[4] Dickey, A. M., Kumar, V., Hoddle, M. S., Funderburk, J. E., Morgan, J. K., Jara-Cavieres A., Shatters, R. G. Jr, Osborne, L. S., McKenzie, C. L. (2015):_The Scirtothrips dorsalis species complex: endemism and invasion in a Global Pest. - PLoS One 10(4): e0123747.

[5] Hamdy, M. K., Salem, M.(1994): The effect of plantation dates of onion, temperature and relative humidity on the population density of the onion thrips, Thrips tabaci Lind. in Egypt. - Annals of Agricultural Science 39(1): 417-424.

[6] Kakkar, G., Seal, D. R., Kumar, V. (2012a): Assessing abundance and distribution of an invasive thrips Frankliniella schultzei (Thysanoptera: Thripidae) in South Florida. Bulletin of Entomological Research 102: 249-259.

[7] Kakkar, G., Seal, D. R., Stansly, P. A., Liburd, O. E., Kumar, E. (2012b): Abundance of Frankliniella schultzei (Thysanoptera: Thripidae) in flowers on major vegetable crops of South Florida. - Florida Entomologist 95(2): 468-475.

[8] Kang, L., Chen, B., Wei, J. N., Liu, T. X. (2009): Roles of thermal adaptation and chemical ecology in Liriomyza distribution and control. - Annal. Review of Entomology 54: $127-145$.

[9] Kirk, W. (1997): Feeding. In: Lewis, T. (ed.) Thrips as Crop Pest, pp.119-174. - CAB International, Wallingford.

[10] Lewis, J. S., Farnsworth, M. L., Burdett, C. L., Theobald, D. M., Gray, M., Miller, R. S. (2017): Biotic and abiotic factors predicting the global distribution and population density of an invasive large mammal. - Scientific Report 7: 441-452.

[11] Mandal, R. N., Bar, R. (2013): The sacred lotus: An incredible wealth of wetlands. Resonance 18(8): 732-737.

[12] Mannion, C. M., Derksen, A. I., Seal, D. R., Osborne, L. S., Martin, C. G. (2014): Population dynamics of Scirtothrips dorsalis (Thysanoptera: Thripidae) and other thrips species on two ornamental host plant species in Southern Florida. - Environmental Entomology 43(4): 849-858.

[13] Milne, J. R., Jhumlekhasing, M., Walter, G. H. (1996): Understanding Host Plant Relationships of Polyphagous Flower Thrips, a Case Study of Frankliniella schultzei (Trybom). In: Goodwin S, Gillespie, P. (eds) - Proceedings of the 1995 Australia and New Zealand Thrips Workshop: Methods, Biology, Ecology and Management, pp. 8-14. NSW Agriculture, Gosford.

[14] Milne, M., Walter, G. H., Milne, J. R. (2002): Mating aggregations and mating success in the flower thrips, Frankliniella schultzei (Thysanoptera: Thripidae), and a possible role for pheromones. - Journal of Insect Behavior 15: 351-368.

[15] Moritz G, Brandt S, Triapitsyn, S., Subramanian, S. (2013): Identification and Information Tools For Pest Thrips in East Africa. - Centre for Pest Information Technology and Transfer, The University of Queensland, Brisbane. 
[16] Mound, L. A., Palmer, J. M. (1981): Identification, distribution and host plants of the pest species of Scirtothrips. (Thysanoptera: Thripidae). - Bulletin of Entomological Research 71: 467-479.

[17] Mungnimitr, S., Bumroongsook, S. (2007): Identification of Frankliniella schultzei (Trybom) and Scirtothrips dorsalis Hood on Nelumbo nucifera Gaertn by ITS-RFLP. The Proceeding of IWGS Annual Symposium, SuanLuang Rama IX Public Park, Bangkok.

[18] Nagata, T., De Avila, A. C. (2000): Transmission of chrysanthemum stem necrosis virus, a recently discovered tospovirus, by thrips species. - Journal of Phytopathology 148: 123125.

[19] Salguero_Navas, V. E., Funderburk, J. E., Beshear, R. J., Olson, S. M., Mack, T. P. (1991): Seasonal patterns of Frankliniella spp. (Thysanoptera: Thripidae) in tomato flowers. - Journal of Economic Entomology 84: 1818-1822.

[20] Seal, D. R., Klassen, W. (2008): Chilli Thrips, Scirtothrips dorsalis Hood (Thysanoptera: Thripidae). In: Capinera, J. L. (eds.) Encyclopedia of Entomology. - Springer, Dordrecht.

[21] Seymour, R. S., Schultze-Motel, P. (1996): Thermoregulating lotus flowers. - Nature 383: 305.

[22] Seymour, R. S., Schultze-Motel, P., Lamprecht, I. (1998): Heat production by sacred lotus flower depends on ambient temperature, not light cycle. - Journal of Experimental Botany 49: 1213-1217.

[23] Shuaib, M., Khan, S. H., Mulghani, N. A. (2008): Effect of temperature and relative humidity on population dynamics of sucking insect pests of cotton (Gossypium hirsutum L.). - ENDURE International Conference 2008: Diversifying Crop Protection, 12-15 October 2008, La Grande-Motte, France.

[24] Waiganjo, M. M., Gitonga, L. M., Mueke, J. M. (2008): Effects of weather on thrips population dynamics and the implication on the thrips management. - African Journal of Horticultural Science 1: 82-90.

[25] Xiao, Y. F., Chen, J., Cantliffe, D., McKenzie, C. L., Houben, K., Osborne, L. S. (2011): Establishment of papaya banker plant system for parasitoid, Encarsia sophia (Hymenoptera: Aphilidae) against Bemisia tabaci (Hemiptera: Aleyrodidae) in greenhouse tomato production. - Biological Control 58(3): 239-47.

[26] Yadav, R., Chang, N. T. (2014): Effects of temperature on the development and population growth of the melon thrips, Thrips palmi, on eggplant, Solanum melongena. -J of Insect Science 14: 78. 